\title{
Hyperechoic Strand
}

National Cancer Institute

\section{Source}

National Cancer Institute. Hyperechoic Strand. NCI Thesaurus. Code C113200.

A radiologic finding describing thin lines in an image with a signal higher than that of the surrounding tissue. 